\title{
KINERJA KARYAWAN BANK SYARIAH : EVALUASI FAKTOR-FAKTOR PENGARUHNYA
}

\author{
Aprih Santoso', Sail Barodin', M. Hasan Ma'ruf ${ }^{3}$ \\ ${ }^{1,2)}$ Fakultas Ekonomi Universitas Semarang, Indonesia \\ ${ }^{3)}$ ITB AAS Indonesia Surakarta \\ *Email korespondensi: aprihsantoso@usm.ac.id
}

\begin{abstract}
The problem in this research is the decline in the performance of marketing employees of Bank BRI Syariah Semarang due to not being able to achieve the targets that have been charged. The research aims to evaluate the influence of incentive factors, emotional intelligence, organizational commitment and work morale on employee performance. The population as well as the sample in this study were all marketing employees of Bank BRI Syariah Semarang totaling 40 people (census technique). The analytical tool in this study is multiple linear regression. The results show that incentives, emotional intelligence, organizational commitment and work morale partially have a positive and significant effect on the performance of marketing employees of Bank BRI Syariah Semarang and the adjusted $R$ square value in the regression model is 0.628 or 68.6 percent of employee performance can be explained by variations incentive variables, emotional intelligence, organizational commitment and morale while the remaining 31.4 percent is explained by other variables.
\end{abstract}

Keywords: performance, incentives, emotional, commitment, passion

\section{PENDAHULUAN}

Setiap organisasi yang ingin terus berkembang harus memperhatikan faktor sumber daya yang dimilikinya, diantaranya adalah faktor sumber daya manusia. Maghfiroh (2021) menyatakan bahwa untuk memajukan kualitas Sumber Daya Manusia yang syariah ada tiga dimensi yang harus diperhatikan, yaitu: 1) Dimensi kepribadian. 2) Dimensi produktivitas. 3) Dimensi kreativitas. Oleh karenanya, pemanfaatan sumber daya manusia harus diperlakukan dengan baik agar dapat bekerja dengan efektif, efisien dan mempunyai kinerja yang tinggi. Hal ini disebabkan karena manusia memegang peranan penting bagi pencapaian tujuan organisasi. Tho'in (2016) mengatakan kemampuan SDM tidak dapat dilihat dari satu sisi saja, namun harus mencangkup secara keseluruhan dari daya pikir serta daya fisik seseorang tersebut. Pentingnya memperlakukan karyawan lebih dari sumber daya lainnya dikarenakan manusia memiliki peranan utama dalam memanfaatkan modal dan perlengkapan lainnya, sehingga pihak pimpinan perlu memperhatikan dan mengelola dengan baik sumber daya manusianya agar memiliki kinerja yang baik. kemampuan SDM tidak dapat dilihat dari satu sisi saja, namun harus mencangkup secara keseluruhan dari daya pikir serta daya fisik seseorang tersebut.

Kinerja merupakan salah suatu elemen penting yang harus terdapat dalam sebuah perusahaan dengan tingkat yang ditetapkan sebagai acuan. Kinerja merupakan suatu kondisi yang harus dketahui yang harus dikonfirmasikan kepada pihak tertentu untuk mengetahui tingkat pencapaan hasil suatu instansi dihubungkan dengan sutu visi dan diemban suatu organisasi atau perusahaan yang serta mengetahui dampak positif dan negatif dari suatu kebijakan operasional (Robbins, 2014).

Faktor insentif merupakan salah satu yang dapat mempengaruhi kenaikan atau penurunan kinerja karyawan. Nitisemito

(2015) 
menyatakan insentif adalah penghasilan tambahan yang akan diberikan kepada para karyawan yang dapat memberikan prestasi sesuai dengan yang telah ditetapkan. Fungsi utama dari insentif adalah untuk memberikan tanggung jawab dan dorongan kepada karyawan. Insentif menjamin bahwa karyawan akan mengarahkan usahanya untuk mencapai tujuan organisasi. Tujuan utama pemberian insentif adalah untuk meningkatkan produktivitas kerja individu maupun kelompok. Hasil penelitian sebelumnya dalam berbagai konteks dari Wijayanti (2015), Subianto (2016), Heliawan (2016), Djuwarto, et al. (2017), Andriyana, et al. (2019), Hidayah, et al. (2020) dan Wahyuningsih, et al. (2020) menyatakan bahwa insentif berpengaruh signifikan terhadap kinerja karyawan.

Selain insentif, kecerdasan emosional juga mempengaruhi kinerja karyawan. Goleman (2012) menyatakan bahwa kecerdasan emosional adalah kemampuan seseorang mengatur kehidupan emosinya dengan intelegensi, menjaga keselarasan emosi dan pengungkapannya melalui keterampilan kesadaran diri, pengendalian diri, motivasi diri, empati dan keterampilan sosial. Hasil penelitian sebelumnya dalam berbagai konteks dari Kustiah (2015), Kristiyanti (2015) dan Kuncoro, et al. (2019) menyatakan bahwa kecerdasan emosional berpengaruh positif dan signifikan terhadap kinerja karyawan.

Disisi lain, komitmen organisasi juga mempengaruhi kinerja karyawan. Robbins (2014) menyebutkan komitmen adalah tingkatan dimana seseorang mengidentifikasikan diri dengan organisasi dan tujuan-tujuannya dan berkeinginan untuk memelihara keanggotaannya dalam organisasi. Jadi pengertian komitmen lebih dari sekedar menjadi anggota saja, tetapi lebih dari itu orang akan bersedia untuk mengusahakan pada derajat upaya yang tinggi bagi kepentingan organisasi, demi memperlancar mencapai tujuan organisasi. Hasil penelitian sebelumnya dalam berbagai konteks dari Marsoit, et al. (2017), Prasetyaningrum \& Rukmini (2020) dan Marimin \& Santoso (2020) menyatakan bahwa komitmen organisasi berpengaruh tidak signifikan terhadap kinerja karyawan.

Tidak ketinggalan, semangat kerja juga dapat mempengaruhi kinerja karyawan. Semangat kerja juga diartikan sebagai suatu kegiatan dalam melaksanakan pekerjaan secara cepat dan lebih baik menyelesaikan suatu kegiatan (Nitisemito, 2015). Semangat kerja dapat diukur melalui presensi pegawai di tempat kerja, tanggung jawabnya terhadap pekerjaan, disiplin kerja, kerja sama dengan pimpinan atau teman sejawat dalam organisasi serta tingkat produktivitas kerja. Hasil penelitian sebelumnya dalam berbagai konteks dari Handayani (2016), Syahropi \& Kasmirudin (2016), Pratama \& Wardani (2017) dan Yenti (2019) menyatakan semangat kerja berpengaruh positif dan signifikan terhadap kinerja karyawan.

Permasalahan tentang kinerja banyak terjadi di perusahaan-perusahaan besar ataupun kecil, salah satunya ada pada BRI Syariah Semarang, BRI Kanca Pandanaran Semarang beralamatkan di jalan Majapahit No. 234E Semarang, dengan lokasi di tengah pusat kota, memberikan satu keuntungan yang baik, namun menurut manager bagian pemasaran, masalah yang terjadi adalah karyawan marketing tidak mampu mencapai target yang telah ditetapkan.

Tabel 1. Pencapaian Karyawan Marketing Dalam Penyaluran KUR Tahun 2019

(Dalam Milyar Rp)

\begin{tabular}{lccc}
\hline \multicolumn{1}{c}{ Bulan } & Target & Realisasi & Persen \\
\hline Januari & 6 & 5,8 & 96,67 \\
Pebruari & 6 & 5,1 & 85,00 \\
Maret & 6 & 5,7 & 95,00 \\
April & 6 & 5,2 & 86,67 \\
Mei & 6 & 5,0 & 83.33 \\
Juni & 6 & 5,1 & 85,00 \\
Juli & 6 & 5,3 & 88,33 \\
Agustus & 6 & 5,5 & 91,67 \\
September & 6 & 5,4 & 90,00 \\
Oktober & 6 & 5,0 & 83,33 \\
Nopember & 6 & 5,1 & 85,00 \\
Desember & 6 & 5,7 & 95,00 \\
\hline Jumlah & 72 & 63,9 & 88,75 \\
\hline Rata-rata & 6 & 5,33 & 88,83 \\
\hline
\end{tabular}


Tabel 1 menunjukkan bahwa target 72 milyar pertahun hanya mampu tercapai 63,9 milyar atau sejumlah 88,75 persen saja, Hal ini mengindikasikan menurunnya kinerja karyawan marketing. Adapun tujuan penelitian adalah mengevaluasi pengaruh insentif, kecerdasan emosional, komitmen organisasi dan semangat kerja terhadap kinerja karyawan marketing.

\section{KAJIAN PUSTAKA}

\subsection{Kinerja Karyawan}

Kinerja merupakan salah suatu elemen penting yang harus terdapat dalam sebuah perusahaan dengan tingkat yang ditetapkan sebagai acuan. Kinerja merupakan suatu kondisi yang harus dketahui yang harus dikonfirmasikan kepada pihak tertentu untuk mengetahui tingkat pencapaan hasil suatu instansi dihubungkan dengan sutu visi dan diemban suatu organisasi atau perusahaan yang serta mengetahui dampak positif dan negatif dari suatu kebijakan operasional (Robbins, 2014) . Kinerja juga merupakan suatu fungsi dari motivasi dan kemampuan seseorang untuk menyelesaikan tugas atau pekerjaan (Widhianingrum. 2017) . Konsep kinerja banyak menghiasi kajian dan praktek dibidang manajemen, sebagai salah satu konsep vital yang menentukan gerak dan perkembangan dari manajemen tertentu. Goleman (2012) menyatakan ada faktor-faktor yang mempengaruhi kinerja seseorang, yakni : 1) Faktor individu (kemampuan, keterampilan, latar belakang keluarga, pengalaman tingkat sosial dan demografi seseorang). 2) Faktor psikologis (persefsi, sikap, kepribadian, peran, mtivasi dan kepuasan kerja). 3). Faktor organisasi (struktur organisasi, desain pekerjaan, kepemimpinan, sistem imbalan (reward system). Jika faktor yang mempengaruhi kinerja tersebut dapat dikondisikan dengan baik, maka otomatis kinerja seseorang juga akan semakin meningkat. Dengan demikian tugas manajer ataupun pihak manajer secara umum adalah membuat faktor yang menjunjung keberadaan kinerja tersebut dapat terpenuhi dalam sebauah organisasi ataupun perusahaan. Tujuan tersebut dapat menyangkut berbagai aspek : aspek pasar perusahaan, aspek keinginan untuk mencapai posisi keuangan tertentu dan aspek lingkungan dalam organisasi. Tujuan yang jelas akan membuat manajer dan karyawan bekerja secara teratur dan bersemangat untuk mencapai tujuan tersebut. Perencanaan manajer dan karyawan dalam setahun mendatang meliputi kegiatan yang menyangkut dengan pencapaian tujuan perusahaan. Hasil yang maksimal dari tujuan perusahaan dipengaruhi oleh produktivitas dari karyawannya. Oleh karena itu, sebelum bekerja untuk mencapai tujuan perusahaan perlu diadakan perbaikan kinerja untuk memperbaiki kinerja karyawan. Indikator kinerja karyawan, adalah : Ketepatan waktu, Kerjasama, Gagasan, Pengetahuan teknis,

\subsection{Insentif}

Husnan (2012) menyatakan insentif adalah pengupahan yang memberikan imbalan yang berbeda karena memang prestasi yang berbeda. Insentif adalah suatu bentuk dorongan finansial kepada karyawan sebagai balas jasa perusahaan kepada karyawan atas prestasi karyawan tersebut. Insentif merupakan sejumlah uang yang di tambahkan pada upah dasar yang di berikan perusahaan kepada karyawan. Insentif merupakan penghargaan dalam bentuk uang yang diberikan kepada mereka yang dapat bekerja melampaui standar yang telah ditentukan. Fungsi utama dari insentif adalah untuk memberikan tanggung jawab dan dorongan kepada karyawan. Insentif menjamin bahwa karyawan akan mengarahkan usahanya untuk mencapai tujuan organisasi. Tujuan utama pemberian insentif untuk meningkatkan produktivitas kerja individu maupun kelompok (Panggabean, 2010). Secara lebih spesifik tujuan pemberian insentif dapat dibedakan dua golongan yaitu : 1) bagi Perusahaan memiliki tujuan dari pelaksanaan insentif dalam perusahaan khususnya dalam kegiatan produksi adalah untuk meningkatkan produktivitas kerja karyawan dengan jalan mendorong atau merangsang agar karyawan bekerja lebih bersemangat dan cepat, bekerja lebih disiplin dan bekerja lebih kreatif. 2) Bagi karyawan dengan adanya pemberian insentif karyawan akan 
mendapat keuntungan. Standar prestasi dapat diukur secara kuantitatif, Standar prestasi dapat digunakan sebagai dasar pemberian balas jasa yang diukur dalam bentuk uang agar karyawan lebih giat. Mangkunegara (2013), menyebutkan tipe insentif ada dua yaitu: 1. Finansial insentif merupakan dorongan yang bersifat keuangan yang bukan saja meliputi gaji-gaji yang pantas. Tetapi juga termasuk didalamnya kemungkinan memperoleh bagian dari keuntungan perusahaan dan soal-soal kesejahteraan yang meliputi pemeliharaan jaminan hari tua, rekreasi, kesehatan dan lain-lain. 2. Non finansial insentif keadaan pekerjaan yang memuaskan yang meliputi tempat kerja, jam kerja, tugas dan rekan kerja dan sikap pimpinan terhadap keinginan masing-masing karyawan seperti jaminan pekerjaan, promosi, keluhan-keluhan, hiburanhiburan dan hubungan dengan atasan. Robbins (2014) jenis rencana insentif secara umum, yaitu: 1. Program insentif individual memberikan pemasukan lebih dan di atas gaji pokok kepada karyawan individual yang memenuhi satu standar kinerja individual spesifik. Bonus di tempat diberikan, umumnya untuk karyawan individual, atas prestasi yang belum diukur oleh standar. 2. Program insentif kelompok adalah seperti rencana insentif individual namun memberi upah lebih dan di atas gaji pokok kepada semua anggota tim ketika kelompok atau tim secara kolektif mencapai satu standar yang khusus kinerja, produktivitas atau perilaku sehubungan dengan kerja lainnya. 3. Rencana pembagian laba secara umum merupakan program insentif di seluruh organisasi yang memberikan kepada karyawan satu bagian (share) dari laba organisasi dalam satu periode khusus. 4. Program pembagian perolehan (gain sharing) adalah rencana upah di seluruh organisasi yang dirancang untuk memberi imbalan kepada karyawan atas perbaikan dalam produktivitas organisasi. Indikator insentif (Wijayanti, 2015) adalah :1. Bonus. 2. Kenaikan jabatan. 3. Pengakuan. 4. Lama kerja. 5. Keadilan.

\subsection{Kecerdasan Emosional}

Teori mengenai kecerdasan emosional pertama kali dicetuskan oleh Mayer (2010) yang mendefinisikan EQ (emotional quotient) sebagai kemampuan untuk memahami perasaan diri sendiri, untuk berempati terhadap perasaan orang lain dan untuk mengatur emosi, yang secara bersama berperan dalam peningkatan taraf hidup seseorang. Goleman (2012) menjelaskan bahwa ada beberapa faktor yang mempengaruhi kecerdasan emosi individu yaitu: 1) Lingkungan keluarga dimana kehidupan keluarga merupakan sekolah pertama dalam mempelajari emosi. 2) Lingkungan non keluarga dimana hal ini yang terkait adalah lingkungan masyarakat dan pendidikan. Kecerdasan emosi ini berkembang sejalan dengan perkembangan fisik dan mental. Goleman (2012) menyatakan bahwa faktorfaktor yang mempengaruhi kecerdasan emosi, antara lain: 1) Fisik, dimana secara fisik bagian yang paling menentukan paling berpengaruh terhadap kecerdasan emosi seseorang adalah anatomi saraf emosinya. 2) Psikis dimana kecerdasan emosi selain dipengaruhi oleh kepribadian individu, juga dapat dipupuk dan diperkuat dalam diri individu. Indikator kercerdasan emosional, adalah : 1) Kesadaran diri. 2) Pengaturan diri. 3) Motivasi. 4) Empati. 5) Keterampilan sosial.

\section{Komitmen Organisasi}

Robbins (2014) menyebutkan komitmen adalah tingkatan di mana seseorang mengidentifikasikan diri dengan organisasi dan tujuan-tujuannya dan berkeinginan untuk memelihara keanggotaannya dalam organisasi. Buchanan (2010) menyatakan komitmen organisasi terdiri dari tiga sikap, yaitu perasaan identifikasi dengan misi organisasi, rasa keterlibatan dalam tugas-tugas organisasi, rasa kesetiaan dan cinta pada organisasi sebagai tempat hidup dan bekerja, terlepas dari manfaat dan misi organisasi bagi individu.

Manfaat adanya komitmen dalam organisasi adalah para pekerja yang benar-benar menunjukkan komitmen tinggi terhadap organisasi mempunyai kemungkinan yang jauh lebih besar untuk menunjukkan tingkat partisipasi yang tinggi dalam organisasi, 
memiliki keinginan yang lebih kuat untuk tetap bekerja pada organisasi yang sekarang dan dapat terus memberikan sumbangan bagi pencapaian tujuan, sepenuhnya melibatkan diri pada pekerjaan mereka, karena pekerjaan tersebut adalah mekanisme kunci dan saluran individu untuk memberikan sumbangannya bagi pencapaian tujuan organisasi, keyakinan tentang pentingnya komitmen dalam kaitannya dengan efektivitas organisasi tampak sejalan. Robbins (2014) menyatakan bahwa untuk membentuk komitmen seseorang terhadap organisasi, yaitu menciptakan rasa kepemilikan terhadap organisasi, untuk menciptakan kondisi ini orang harus mengidentifikasi dirinya dalam organisasi, untuk mempercayai bahwa ada guna dan manfaatnya bekerja diorganisasi, untuk merasakan kenyamanan didalamnya, untuk mendukung nilai-nilai, visi, dan misi organisasi dalam mencapai tujuannya.

Salah satu faktor penting dalam menciptakan rasa kepemilikan ini adalah meningkatkan perasaan seluruh anggota organisasi bahwa perusahaan (organisasi) ini adalah benar-benar merupakan milik mereka. Kepemilikan ini tidak sekedar dalam bentuk kepemilikan saham saja (meskipun kadangkala ini juga merupakan cara yang cukup membantu), namun lebih berupa meningkatkan kepercayaan di seluruh anggota organisasi bahwa mereka benar-benar (secara jujur) diterima oleh manajemen sebagai bagian dari organisasi. Banyak cara yang bisa dilakukan untuk itu, mengajak mereka anggota organisasi untuk terlibat memutuskan penciptaan dan pengembangan produk baru, terlibat memutuskan perubahan rancangan kerja dan sebagainya. Bila mereka anggota organisasi merasa terlibat dan semua idenya dipertimbangkan maka muncul perasaan kalau mereka ikut berkontribusi terhadap pencapaian hasil. Apalagi ditambah dengan kepercayaan kalau hasil yang diperoleh organisasi akan kembali pada kesejahteraan mereka pula.

Menciptakan semangat dalam bekerja, cara ini dapat dilakukan dengan lebih mengkonsentrasikan pada pengelolaan faktorfaktor motivasi instrinsik dan menggunakan berbagai cara perancangan pekerjaan. Menciptakan semangat kerja bawahan bisa dengan cara membuat kualitas kepemimpinan yaitu menumbuhkan kemauan manajer dan supervisor untuk memperhatikan sepenuhnya motivasi dan komitmen bawahan melalui pemberian delegasi tanggung jawab dan pendayagunaan ketrampilan bawahan. Indikator komitmen organisasi, adalah :1) Affective commitment. 2) Continuance commitment. 3) Normative commitment

\subsection{Semangat Kerja}

Semangat kerja diartikan sebagai suatu kegiatan dalam melaksanakan pekerjaan secara cepat dan lebih baik menyelesaikan suatu kegiatan (Nitisemito, 2015). Semangat kerja dapat diukur melalui presensi pegawai di tempat kerja, tanggung jawabnya terhadap pekerjaan, disiplin kerja, kerja sama dengan pimpinan atau teman sejawat dalam organisasi serta tingkat produktivitas kerja (Mayer, 2010) .

Aspek-aspek semangat kerja perlu untuk dipelajari karena aspek-aspek ini mengukur tinggi-rendahnya semangat kerja. Mayer (2010), ada empat aspek yang menunjukkan seseorang mempunyai semangat kerja yang tinggi, yaitu: 1) Kegairahan. 2) Kekuatan untuk melawan frustasi. 3) Kualitas untuk bertahan. 4) Semangat kelompok. Indikator semangat kerja (Syahropi \&Kasmirudin, 2016), adalah : 1) Kegairahan. 2) Kekuatan. 3) Kulitas. 4) Presensi. 5) Kedisiplinan.

\subsection{Hipotesis}

Hipotesis yang diajukan oleh peneliti adalah : (H1) : Insentif berpengaruh terhadap kinerja karyawan. (H2): Kecerdasan emosional berpengaruh terhadap kinerja karyawan. (H3): Komitmen organisasi berpengaruh terhadap kinerja karyawan. (H4): Semangat kerja berpengaruh terhadap kinerja karyawan.

\section{METODE PENELITIAN}

Variabel bebas adalah variabel yang mempengaruhi atau yang menjadi sebab perubahan timbulnya variabel terikat (insentif, 
kecerdasan emosional, komitmen organisasi dan semangat kerja).

Variabel terikat adalah variabel yang dipengaruhi atau yang menjadi akibat adanya variabel bebas (kinerja karyawan)

Objek Penelitian dalam penelitian ini adalah seluruh karyawan marketing di Bank BRI Syaiah di Semarang yang berjumlah 40 karyawan. Dalam penelitian ini teknik yang digunakan adalah teknik sensus.

Skala Pengukuran Kuesioner merupakan suatu skala psikometrik yang biasa diaplikasikan dalam angket dan paling sering digunakan untuk riset yang berupa survei. Lima alternatif jawaban responden dengan menggunakan skala 1 adalah Sangat Tidak Setuju (STS) - skala 5 adalah Sangat Setuju (SS).

Metode Analisisnya adalah Deskrptif dengan alat analisis :Uji Validitas. Uji Reliabilitas, Uji normalitas, Uji Multikolonieritas, Uji Heteroskedasitas, Uji t (Uji Hipotesis) dan Koefisien Determinasi (R2) serta Regresi Linier Berganda, Persamaan regresinya adalah:

$\mathrm{Y}=\mathrm{a}+\mathrm{b} 1 \mathrm{X} 1+\mathrm{b} 2 \mathrm{X} 2+\mathrm{b} 3 \mathrm{X} 3+\mathrm{b} 4 \mathrm{X} 4+\mathrm{e}$

Dimana :

$\mathrm{Y}=$ Kinerja karyawan

$\mathrm{X} 1=$ Insentif

$\mathrm{X} 2=$ Kecerdasan emosional

$\mathrm{X} 3=$ Komitmen organisasi

$\mathrm{X} 4=$ Semangat kerja

$\mathrm{a}=$ Konstanta

b1,b2,b3,b4 = Koefisien regresi

$\mathrm{e}=$ Error / tingkat kesalahan yang dapat ditolerir.

\section{HASIL DAN PEMBAHASAN}

\section{Hasil Uji Validitas}

Tabel 2. Hasil Uji Validitas

\begin{tabular}{llc}
\hline & Variabel & r hit.>r tab.(0,263) \\
\hline \multirow{3}{*}{ Insentif } & Indikator X1.1 & 0.909 \\
& Indikator X1.2 & 0.917 \\
& Indikator X1.3 & 0.856 \\
& Indikator X1.4 & 0.865 \\
\hline
\end{tabular}

\begin{tabular}{cll}
\hline & Indikator X1.5 & 0.955 \\
& Indikator X2.1 & 0.898 \\
Kecerdasan & Indikator X2.2 & 0.906 \\
emosional & Indikator X2.3 & 0,886 \\
& Indikator X2.4 & 0,882 \\
& Indikator X2.5 & 0,921 \\
Komitmen & Indikator X3.1 & 0,950 \\
organisasi & Indikator X3.2 & 0,881 \\
& Indikator X3.3 & 0,964 \\
& Indikator X4.1 & 0,950 \\
Semangat & Indikator X4.2 & 0,831 \\
kerja & Indikator X4.3 & 0,931 \\
& Indikator X4.4 & 0,902 \\
& Indikator X4.5 & 0,909 \\
Kinerja & Indikator Y2 & 0,903 \\
karyawan & Indikator Y3 & 0,794 \\
& Indikator Y4 & 0,880
\end{tabular}

Tabel 2 menunjukkan semua indikator mempunyai $\mathrm{r}$ hitung $>\mathrm{r}$ table maka dikatakan valid.

\section{Hasil Uji Reliabilitas}

Tabel 3. Hasil Uji Reliabilitas

\begin{tabular}{clc}
\hline & Variabel & Koef. alpha>0,60 \\
\hline \multirow{4}{*}{ Insentif } & Indikator X1.1 & 0.942 \\
& Indikator X1.2 & 0.938 \\
& Indikator X1.3 & 0.952 \\
& Indikator X1.4 & 0.924 \\
& Indikator X1.5 & 0.936 \\
& Indikator X2.1 & 0.925 \\
Kecerdasan & Indikator X2.2 & 0.925 \\
emosional & Indikator X2.3 & 0,929 \\
& Indikator X2.4 & 0,929 \\
& Indikator X2.5 & 0,920 \\
& Indikator X3.1 & 0,849 \\
Komitmen & Indikator X3.2 & 0,946 \\
organisasi & Indikator X3.3 & 0,846 \\
& Indikator X4.1 & 0,920 \\
Semangat & Indikator X4.2 & 0,948 \\
kerja & Indikator X4.3 & 0,924 \\
& Indikator X4.4 & 0,932
\end{tabular}




\begin{tabular}{cll}
\hline & Indikator X4.5 & 0,931 \\
& Indikator Y1 & 0,853 \\
Kinerja & Indikator Y2 & 0,796 \\
karyawan & Indikator Y3 & 0,854 \\
& Indikator Y4 & 0,808 \\
\hline
\end{tabular}

Tabel 3 menunjukkan semua variabel mempunyai koefisien Alpha > 0,60 sehingga reliabel.

\section{Hasil Uji Normalitas}

Tabel 4 Hasil Uji Normalitas One-Sample Kolmogorov-Smirnov Test

\begin{tabular}{llr}
\hline \multicolumn{2}{c}{ One-Sample Kolmogorov-Smirnov Test } \\
\hline & Mean & $\begin{array}{r}\text { Unstandardized } \\
\text { Residual }\end{array}$ \\
\hline $\mathrm{N}$ & & 40 \\
Normal Parameters & Std. & \\
& Deviation & 1,60759821 \\
Most Extreme & Absolute &, 117 \\
Differences & Positive &, 117 \\
Kolmogorov-Smirnov Z &,- 097 \\
Asymp. Sig. (2-tailed) &, 740 \\
a. Test distribution is Normal. &, 644 \\
\hline
\end{tabular}

Tabel 4 menunjukkan signifikansi sebesar 0.644 $>0,05$ artinya nilai residuals sudah terdistribusi normal.

\section{Hasil Uji Multikolonieritas}

Tabel 5. Hasil Uji Multikolonieritas

\begin{tabular}{|c|c|c|c|c|c|}
\hline \multirow{2}{*}{\multicolumn{2}{|c|}{ Model }} & \multirow[b]{2}{*}{$\mathrm{T}$} & \multicolumn{3}{|c|}{$\begin{array}{l}\text { Collinearity } \\
\text { Statistics }\end{array}$} \\
\hline & & & Sig. & $\begin{array}{c}\text { Tole } \\
\text { Rance }\end{array}$ & VIF \\
\hline \multirow[t]{5}{*}{1} & (Constant) & -.013 & .990 & & \\
\hline & Insentif & 2.237 & .032 & .500 & 2.002 \\
\hline & $\begin{array}{l}\text { Kecerdasan } \\
\text { emosional }\end{array}$ & 2,762 & ,009 & .597 & 1,674 \\
\hline & Komitmen organisasi & 2,112 & .042 & .720 & 1.338 \\
\hline & Semangat kerja & 2.066 & .046 & .559 & 1.790 \\
\hline
\end{tabular}

a. Dependent

Variable: Kinerja

karyawan
Tabel 5 menunjukkan semua nilai VIF dari variabel bebas memiliki nilai $<10$ artinya antar variabel independen tidak terjadi korelasi.

\section{Hasil uji Heteroskedastisitas}

Tabel 6. Hasil Uji Heteroskedastisitas

\begin{tabular}{|c|c|c|c|}
\hline & $\begin{array}{l}\text { Standardized } \\
\text { Coefficients }\end{array}$ & & \\
\hline Model & Beta & $\mathrm{T}$ & Sig. \\
\hline 1 (Constant) & & .802 & .415 \\
\hline $\begin{array}{l}\text { Insentif } \\
\text { Keceerdasan }\end{array}$ & .187 & .829 & .413 \\
\hline emosional & -.238 & -1.153 & .257 \\
\hline $\begin{array}{l}\text { Komitmen } \\
\text { organisasi }\end{array}$ & .299 & 1.594 & .120 \\
\hline \multicolumn{4}{|l|}{ Semangat kerja } \\
\hline & -.042 & -.199 & .844 \\
\hline
\end{tabular}

a. Dependent Variable: ABS_RES

Tabel 6 menunjukkan semua variabel independen mempunyai nilai signifikansi $>0,05$, artinya tidak terjadi ketidaksamaan variance dari pengamatan satu dengan pengamatan lainnya.

\section{Hasil Analisis Regresi Linear Berganda:}

Tabel 7. Hasil Uji Regresi Linier Berganda

\begin{tabular}{|c|c|c|c|}
\hline & $\begin{array}{l}\text { Standardized } \\
\text { Coefficients }\end{array}$ & & \\
\hline Model & Beta & $\mathrm{t}$ & Sig. \\
\hline 1 (Constant) & & -.013 & .990 \\
\hline Insentif & .284 & 2.237 & .032 \\
\hline $\begin{array}{l}\text { Kecerdasan } \\
\text { enosional }\end{array}$ & .321 & 2.762 & .009 \\
\hline $\begin{array}{l}\text { Komitmen } \\
\text { organisasi }\end{array}$ & .223 & 2.112 & .042 \\
\hline Semangat kerja & .248 & 2.066 & .046 \\
\hline
\end{tabular}

Berdasarkan tabel 7 maka dapat dibuat persamaan :

Kinerja karyawan $=0,284$ Insentif $+0,321$ Kecerdasan emosional $+0,223$ Komitmen organisasi $+0,248$ Semangat kerja, artinya :

1. Hasil B1 menunjukkan hasil sebesar 0,285 dan bernilai positif berarti apabila insentif ditingkatkan maka kinerja karyawan akan meningkat. 
2. Hasil B2 menunjukkan menunjukkan hasil sebesar 0,321 dan bernilai positif berarti apabila kecerdasan emosional ditingkatkan maka kinerja karyawan akan meningkat.

3. Hasil B3 menunjukkan menunjukkan hasil sebesar 0,223 dan bernilai positif berarti apabila komitmen organisasi ditingkatkan maka kinerja karyawan akan meningkat.

4. Hasil B4 menunjukkan menunjukkan hasil

\begin{tabular}{|c|c|c|c|c|}
\hline \multicolumn{5}{|c|}{ Model Summary ${ }^{\text {b }}$} \\
\hline Model & $\mathrm{R}$ & $\begin{array}{l}\mathrm{R} \\
\text { Square }\end{array}$ & $\begin{array}{l}\text { Adjusted } \\
\text { R Square }\end{array}$ & $\begin{array}{l}\text { Std. Error of } \\
\text { the Estimate }\end{array}$ \\
\hline 1 &, $847^{\mathrm{a}}$ & ,718 & ,686 & 1,69698 \\
\hline
\end{tabular}

ar 0,248 dan bernilai positif berarti apabila semangat kerja ditingkatkan maka kinerja karyawan akan meningkat.

\section{Hasil Uji t}

Tabel 8. Hasil Uji t

\begin{tabular}{|c|c|c|c|c|}
\hline Model & & $\begin{array}{c}\text { Standardized } \\
\text { Coefficients } \\
\text { Beta }\end{array}$ & $\mathrm{T}$ & Sig. \\
\hline \multirow{5}{*}{1} & (Constant) & & 1,859 &, 074 \\
\hline & Insentif & ,590 & ,963 & ,000 \\
\hline & $\begin{array}{l}\text { Kecerdasan } \\
\text { emosional }\end{array}$ & ,639 & 2,455 & ,049 \\
\hline & $\begin{array}{l}\text { Komitmen } \\
\text { organisasi }\end{array}$ & ,363 & 2,039 & ,005 \\
\hline & Semangat kerja &,- 112 &,- 589 & ,323 \\
\hline
\end{tabular}

a. Dependent Variable: Kinerja karyawan

Berdasarkan tabel 8 dapat dijelaskan sebagai berikut :

1. Pengaruh Insentif Terhadap Kinerja Karyawan

Nilai signifikansi sebesar $0,032<0,05$ maka hipotesis diterima, artinya insentif berpengaruh positif dan signifikan terhadap kinerja karyawan.

2. Pengaruh Kecerdasan Emosional Terhadap Kinerja Karyawan

Nilai signifikansi sebesar $0,009<0,05$ maka hipotesis 2 diterima, artinya kecerdasan emosional berpengaruh positif dan signifikan terhadap kinerja karyawan.
3. Pengaruh Komitmen Organisasi Terhadap Kinerja Karyawan

Nilai signifikansi sebesar $0,042<0,05$ maka hipotesis 3 diterima, artinya komitmen organisasi berpengaruh positif dan signifikan terhadap kinerja karyawan.

4. Semangat Kerja Terhadap Kinerja Karyawan

Nilai signifikansi sebesar $0,046<0,05$ maka hipotesis 4 diterima, artinya semangat kerja berpengaruh positif dan signifikan terhadap kinerja karyawan.

\section{Hasil Koefisien Deteterminasi (R2)}

\section{Tabel 9. Hasil Uji Koefisien Determinasi}

Tabel 9 menunjukkan nilai adjusted $R$ square sebesar 0,686 atau $68,6 \%$ artinya variabel kinerja karyawan dapat dijelaskan oleh variasi variabel insentif, kecerdasan emosional, komitmen organisasi dan semangat kerja sebesar $68,6 \%$, sedangkan sisanya sebesar $31,4 \%$ dijelaskan oleh variabel lain diluar penelitian ini, seperti : motivasi, locus of control, disiplin kerja.

\section{Pembahasan}

\section{Pengaruh Insentif Terhadap Kinerja Karyawan}

Hasil penelitian menunjukkan insentif berpengaruh positif dan signifikan terhadap kinerja karyawan artinya apabila insentif ditingkatkan maka akan mampu meningkatkan kinerja karyawan. Pemberian insentif dari Bank Syariah Semarang dapat meningkatkan kinerja karyawan marketingnya terhadap output yang dihasilkan. Karyawan marketing merasa insentif yang sudah diterimanya telah tepat karena selalu dapat memenuhi kebutuhan hidup yang akhirnya berdampak pada kinerja karyawan marketing Bank BRI Syariah Semarang terebut. Hasil penelitian ini juga dapat memperjelas dan memperkuat teori-teori yang sudah dipaparkan pada bagian kajian pustaka di atas bahwa insentif berpengaruh terhadap kinerja. Begitu juga dari teori yang dikemukakan oleh Panggabean (2010) yang menyatakan bahwa tujuan utama pemberian insentif untuk 
meningkatkan produktivitas kerja individu maupun kelompok. Disisi lain, hasil penelitian ini juga mendukung hasil penelitian sebelumsebelumnya dari berbagai konteks yaitu : Wijayanti (2015), Subianto (2016), Heliawan (2016), Djuwarto, et al. (2017), Andriyana, et al. (2019), Hidayah, et al. (2020) dan F Wahyuningsih, et al. (2020) yang menyatakan insentif berpengaruh positif dan signifikan terhadap kinerja karyawan.

\section{Pengaruh Kecerdasan Emosional Terhadap Kinerja Karyawan}

Hasil penelitian menunjukkan kecerdasan emosional berpengaruh positif dan signifikan terhadap kinerja karyawan artinya apabila kecerdasan emosional ditingkatkan maka akan mampu meningkatkan kinerja karyawan. Maknanya bahwa karyawan marketing Bank BRI Syariah Semarang sudah memiliki kecerdasan emosinal (emotional quotient) sehingga dapat membantu karyawan marketing Bank Syariah Semarang tersebut dalam mengatur emosi yang timbul saat pelaksanaan kinerja marketingnya serta mampu menangani pekerjaan dengan optimal. Hasil penelitian ini juga dapat memperjelas dan memperkuat teori-teori yang sudah dipaparkan pada bagian kajian pustaka di atas bahwa kecerdasan emosional berpengaruh terhadap kinerja. Begitu juga dari teori yang dikemukakan oleh Mayer (2010) yang mendefinisikan EQ (emotional quotient) sebagai kemampuan untuk memahami perasaan diri sendiri, untuk berempati terhadap perasaan orang lain dan untuk mengatur emosi, yang secara bersama berperan dalam peningkatan taraf hidup seseorang. Disisi lain, hasil penelitian ini juga mendukung hasil penelitian sebelumnya dalam berbagai konteks dari Kustiah (2015), Kristiyanti (2015) dan Kuncoro, et al. (2019) yang menyatakan kecerdasan emosional berpengaruh positif dan signifikan terhadap kinerja karyawan.

\section{Pengaruh Komitmen Organisasi Terhadap Kinerja Karyawan}

Hasil penelitian menunjukkan komitmen organisasi berpengaruh positif dan signifikan terhadap kinerja karyawan artinya apabila komitmen organisasi ditingkatkan maka akan mampu meningkatkan kinerja karyawan. Temuan ini menunjukkan bahwa semakin tinggi komitmen organisasi yang dimiliki karyawan marketing Bank Syariah Semarang ternyata kinerja yang dihasilkkannya semakin tinggi. Karyawan marketing Bank BRI Syariah Semarang memiliki komitmen tinggi terhadap Bank Syariah Semarang dimana tempat mereka bekerja, sudah menunjukkan loyalitas, rasa identifikasi, merasa senang bekerja, memiliki sense of belonging (rasa memiliki organisasi), bertanggung jawab dan terlibat lebih banyak. Otomatis, bila komitmen organisasi yang dimiliki karyawan marketing Bank BRI Syariah Semarang semakin tinggi maka kinerjanya akan semakin baik. Hasil penelitian ini juga dapat memperjelas dan memperkuat teori-teori yang sudah dipaparkan pada bagian kajian pustaka di atas bahwa kecerdasan emosional berpengaruh terhadap kinerja. Begitu juga dari teori yang dikemukakan oleh F Buchanan (2010) menyatakan komitmen organisasi terdiri dari tiga sikap, yaitu perasaan identifikasi dengan misi organisasi, rasa keterlibatan dalam tugas-tugas organisasi, rasa kesetiaan dan cinta pada organisasi sebagai tempat hidup dan bekerja, terlepas dari manfaat dan misi organisasi bagi individu. Hasil penelitian ini juga mendukung hasil penelitian sebelumnnya dalam berbagai konteks, yaitu : Marsoit, et al. (2017), Prasetyaningrum \& Rukmini (2020) dan Marimin \& Santoso (2020) yang menyatakan komitmen organisasi berpengaruh positif dan signifikan terhadap kinerja karyawan.

\section{Pengaruh Semangat Kerja Terhadap Kinerja Karyawan}

Hasil penelitian menunjukkan semangat kerja berpengaruh positif dan signifikan terhadap kinerja karyawan artinya apabila semangat kerja ditingkatkan maka akan meningkatkan kinerja karyawan. Semangat kerja yang menyatakan bahwa karyawan marketing menilai jika pelaksanaan semangat kerja yang dilakukan pada 
Bank BRI Syariah Semarang sudah tepat. Hal ini berarti dimensi yang digunakan oleh peneliti dalam menguji variabel semangat kerja telah sesuai dengan yang diberlakukan oleh Bank BRI Syariah Semarang dalam hal ini berarti semakin baik semangat kerja dari karyawan marketing maka semakin baik pula kinerja karyawan marketing Bank BRI Syariah Semarang. Hasil penelitian ini juga dapat memperjelas dan memperkuat teori-teori yang sudah dipaparkan pada bagian kajian pustaka di atas bahwa semangat kerja berpengaruh terhadap kinerja. Selain itu, juga dapat membuktikan teori yang dikemukan oleh Syamsudin (2005) yang mengatakan bahwa kinerja dipengaruhi oleh 3 (tiga) faktor, yaitu semangat kerja pegawai, pengalaman pegawai, dan pengawasan dari pemimpin. Hasil penelitian ini mendukung hasil penelitian sebelumnya dalam berbagai konteks, yaitu : Handayani (2016), Syahropi \& Kasmirudin (2016), Pratama \& Wardani (2017) dan Yenti (2019) yang menyatakan semangat kerja berpengaruh positif dan signifikan terhadap kinerja karyawan.

\section{Kesimpulan}

Insentif, kecerdasan emosional, komitmen organisasi dan semangat kerja, berpengaruh terhadap kinerja karyawan marketing Bank BRI Syariah Semarang artinya apabila insentif, kecerdasan emosional, komitmen organisasi dan semangat kerja, ditingkatkan maka akan meningkatkan kinerja karyawan marketing Bank BRI Syariah Semarang.

\section{IMPLIKASI}

Bank BRI Syariah Semarang agar : (1) Tidak lagi menggunakan seberapa lama karyawan bekerja namun berdasarkan kinerja atau pencapain karyawan marketing dalam bekerja. Memberikan gathering atau acara bersama untuk menumbuhkan rasa empati sesama karyawan. (3) Aktif mendampingi karyawan marketing agar karyawan mencintai pekerjaan yang dikerjakan. (4) Memberikan pengawasan yang optimal sehingga karyawan lebih bersemangat dalam bekerja. (5) memberikan pelaporan bersifat lisan dan tulisan agar karyawan mengutamakan teknis yang sesuai prosedur yang telah berlaku.

\section{UCAPAN TERIMA KASIH}

Peneliti mengucapkan terima kasih kepada pihak-pihak yang telah membantu selesainya penelitian ini dan kepada pihak pengelola JIEI (Jurnal Ilmiah Ekonomi Islam) ITB AAS Indonesia Surakarta yang telah berkenan menerbitkan artikel ini.

\section{REFERENSI}

Andriyana, S., Istiatin, Damayanti, R.. (2019). Peningkatan Kinerja Pegawai Ditinjau Dari Kompetensi, Insentif Dan Disiplin Di Balai Pengelolaan Sumber Daya Air Bengawan Solo. Jurnal Ilmiah Edunomika. 03(01). 180-185. DOI : 10.29040/jie.v3i01.447

Buchanan, T. (2010). Manajemen Sumber Daya Manusia Jilid Satu. Bogor: Ghalia Indonesia.

Djuwarto, Istiatin, Hartono, S. ( 2017). Pengaruh Insentif, Kompetensi, Dan Lingkungan Kerja Terhadap Kinerja Pegawai Dinas Pekerjaan Umum Kabupaten Sukoharjo. JAP (Jurnal Akuntansi dan Pajak). 18(01).83-93.

DOI: http://dx.doi.org/10.29040/jap.v18i01. $\underline{86}$

Goleman. (2012). Manajemen Sumber Daya Manusia Jilid 2. Bandung: Alfabeta.

Malayu H. (2012). Manajemen SDM. Edisi Revisi, Cetakan Ke Tigabelas. Jakarta : Bumi Aksara.

Heliawan, YA. (2016). Analisis Kinerja Karyawan Pt Novell Pharmaceutical Laboratories Dengan Menggunakan Variabel Kompensasi, Lingkungan Kerja Dan Motivasi. JAP (Jurnal Akuntansi Dan Pajak). 16(02). 1-14. DOI: http://dx.doi.org/10.29040/jap.v16i02. $\underline{17}$

Hidayah, R.N., Kustiyah, E. \& Hartono, S. (2020). Kinerja Karyawan Ditinjau Dari Promosi Jabatan , Kompetensi , Dan Insentif Pada Karyawan PT Pos Indonesia 
(Persero) Cabang Surakarta. Jurnal Ilmiah Edunomika. $\quad 4(01) . \quad 88-95$ DOI: http://dx.doi.org/10.29040/jie.v4i01.8 $\underline{13}$

Husnan. (2012). Manajemen Sumber Daya Manusia. Jakarta. Erlangga

Kuncoro, T.W., Sudarwati, Djumali (2019). Pengaruh Kecerdasan Emosional, Kompetensi, Dan Motivasi Terhadap Kinerja Pegawai Setda Kabupaten Wonogiri. Jurnal Ilmiah Edunomika. 03(02). 310-317.

Kustiah, R. (2015). Pengaruh kecerdasan emosional, kemampuan SDM dan efektifitas terhadap kinerja karyawan. Jurnal Manajemen Dan Bisnis. 4(2).

Kristiyanti, LMS.. (2015). Pengaruh Emotional Quotient Dan Self Efficacy Terhadap Kinerja Auditor (Studi Kasus Kantor Akuntan di Surakarta dan Yogyakarta). JAP (Jurnal Akuntansi Dan Pajak). 16(01), 88102. DOI : $\underline{10.29040 / \text { jap.v16i01.24 }}$

Maghfiroh, A. (2021). Analisis Pengembangan Sumber Daya Manusia Dalam Perspektif Syariah. JIEI (Jurnal Ilmiah Ekonomi Islam $)$ 7(01), 403-411. DOI : 10.29040/jiei.v7i1.2138

Mangkunegara, AP. (2013). Manajemen Sumber Daya Manusia. Jakarta: Erlangga.

Marimin, A \& Santoso, H. (2020). Analisis Pengaruh Kepuasan Kerja, Komitmen Organisasi, dan Keterlibatan Kerja Pada Kinerja Karyawan Bank Muamalat Surakarta. JIEI (Jurnal Ilmiah Ekonomi Islam $)$ 6(03), 703-708. DOI : 10.29040/jiei.v6i3.1467

Marsoit, P., Greis S. \& Farlane R.. (2017). Pengaruh pelatihan, disiplin kerja dan komitmen organisasi terhadap kinerja karyawan. Jurnal Manajemen Bisnis. 4(5).

Mayer, A. (2010). Manajemen Sumber Daya Manusia. Bogor: Ghalia Indonesia.

Nitisemono. A. (2015), Manajemen Sumber Daya Manusia, Bandung. Pustaka Setia

Panggabean, Mutiara S. (2010). Manajemen Sumber Daya Manusia. Bogor: Ghalia Indonesia.

Prasetyaningrum, Nurita E. Rukmini. (2020).
Pengaruh Komitmen Organisasi Terhadap Kinerja Auditor Dengan Independensi, Integritas dan Pemahaman Good Governance Sebagai Variabel Pemoderasi (Studi Empiris pada KAP di Jawa Tengah dan DIY). JAP (Jurnal Akuntansi dan Pajak). 21 (01), 112-120.

DOI: http://dx.doi.org/10.29040/jap.v21i1.1 $\underline{084}$

Pratama, A.A.N \& Wardani, A. (2017). Pengaruh kemampuan kerja, semangat kerja dan kepuasan kerja terhadap kinerja karyawan. Jurnal Manajemen Sumber Daya Manusia. 4(3).

Robbins, S.P. (2014). Manajemen Sumber Daya Manusia Jilid II. Bandung: Alfabeta.

Subianto, M. (2016). Pengaruh gaji dan insentif terhadap kinerja karyawan. Jurnal Manajemen Dan Bisnis .4(3).

Syahropi, Ishak \& Kasmirudin. (2016). Pengaruh Semangat Kerja Terhadap Kinerja Karyawan PT. Bangkinang Di Pekanbaru (Studi Kasus Pada Karyawan Tetap PT. Bangkinang). JOM FISIP. 3(2). 1-12.

Syamsudin, A. (2005). Psikologi Pendidikan. Bandung: PT. Remaja Rosdakarya Syahropi, Ishak. (2016). Pengaruh semangat kerja terhadap kinerja karyawan. Jurnal EMBA. 5(4).

Tho'in. M. (2016). Kompetensi Sumber Daya Manusia Bank Syariah Berdasarkan PrinsipPrinsip Syariah Islam. JIEI (Jurnal Ilmiah Ekonomi Islam). 02(03). 158-171. DOI : 10.29040/jiei.v2i03.49

Wahyuningsih, Hartono, S. Djumali. (2020). Budaya Kerja, Kedisiplinan Dan Insentif Terhadap Kinerja Karyawan Universitas Tunas Pembangunan (UTP) Surakarta. Jurnal Ilmiah Edunomika. 04(01). 50-54. DOI : $\underline{10.29040 / j i e . v 4 i 01.834}$

Widhianingrum, W. (2017). Pengaruh Motivasi Terhadap Kinerja Karyawan BRI Syariah Magetan. JIEI (Jurnal Ilmiah Ekonomi Islam), 3(03), 193-198. DOI : 10.29040/jiei.v3i03.124

Wijayanti, R.Y. (2015). Pengaruh kedisiplinan dan insentif terhadap kinerja karyawan. Jurnal EMBA 6(2). 
Yenti, S. (2019). Pengaruh Semangat Kerja Terhadap Kinerja Perangkat Nagari Dalam Pengelolaan Keuangan Nagari Di Kabupaten Pesisir Selatan. JESS (Journal of Education on Social Science). 3(2), 79-90. DOI: https://doi.org/10.24036/jess/vol3-iss2 